\title{
GONAD MATURITY STAGES OF ANCHOVIES (Encrasicholina heterolobus) FROM BACAN ISLAND
}

\author{
Retno Andamari ${ }^{*}$, Margaret Farmer ${ }^{* *}$, Umi Khodriyah ${ }^{* *+}$ and \\ Andriko N. Susanto*)
}

\begin{abstract}
The gonad maturity stages of anchovies (Encrasicholina heterolobus) used as tuna baitfish were examined in the waters of Bacan Island. The species is a multiple spawner with asynchronous oocyte development. From 1165 female E. heterolobus gonads examined histologically, an average of $40 \%$ were spent (post-vitellogenic follicles present) at any one time
\end{abstract}

KEYWORDS: anchovies, Encrasicholina, gonad maturity.

\section{INTRODUCTION}

One of the important fisheries in Maluku is the pole-and-line fishery for skipjack tuna. This fishery depends on a consistent supply of anchovies that are used as live bait. The variability in the supply of anchovies to the fishery has led to calls for accurate assessment of the stocks of these fish in the baitgrounds. One of the objectives of the collaborative baitfish research project between CSIRO and RIMF was to evaluate the Daily Egg Production Method (DEPM) for estimating anchovy biomass. One of the parameters needed for this estimation method was the spawning frequency and gonad maturity of anchovies at the same time that the plankton was sampled for their eggs. The objective of the part of the study reported in this paper was to describe the gonad maturation and spawning frequency (using the presence of post-vitellogenic follicles) of the anchovy Encrasicholina heterolobus in the Bacan area of Maluku.

\section{MATERIAL AND METHODS}

\section{Sampling}

Fish were collected from "bagans" at Bacan Is. land in September and November 1996, and April and July 1997. All fish were preserved in $10 \%$ formalin and taken to the laboratory of the Ambon Assessment Institute of Agricultural Technology.

\section{Laboratory Study}

All fish from the samples were measured (standard length in $\mathrm{mm}$ ) and weighed $( \pm 0.001 \mathrm{~g})$. Gonads were removed from female fish and preserved in $70 \%$ alcohol for subsequent histological preparation. For histological processing half of each ovary was dehydrated in a graded series of alcohols, cleared in xylene, impregnated with and embedded in paraffin wax. Six-micrometer serial sections were stained with haematoxylin and eosin (Luna, 1968), then mounted and examined.

Gonad maturity was defined following the stages of Hunter \& Goldberg (1980) and Cyrus and Blaber (1984). These criteria are shown in Table 1. The gonads were scored according to the relative number of cells of each developmental stage, and the presence of post-ovulatory follicles was noted. The percentage of each histological section that corresponded to each developmental stage was subjectively estimated.

\section{RESULTS AND DISCUSSIONS}

The gonads of 1165 female Encrasicholina heterolobus were examined histologically and all contained oocytes in each of the various stages of development. This indicates that this baitfish has asynchronous oocyte development and multiple spawning, supporting previous research. Sumadhiharga (1995) found that the three species of Encrasicholina (Stolephorus) in Ambon Bay had

\footnotetext{
*) Ambon Assessment Institute of Agricultural Technology. Jl. Chr. Soplanit, Rumah Tiga, Ambon 97233, Indonesia

**) CSIRO Marine Research, PO Box 120, Cleveland 4163 Qld.. Australia

$* * *)$ Research Institute for Marine Fisheries
} 
Table 1. Criteria used for staging female gonads of Encrasicholina spp.

\begin{tabular}{cll}
\hline Stage & \multicolumn{1}{c}{ Remarks } & \multicolumn{1}{c}{ Histology } \\
\hline 1 & Immature & Oogonia present \\
2 & Developing/resting & Pre-vitellogenic oocytes \\
3 & Maturing & Yolk precursor stage; some non-staining yolk \\
4 & Ripe & Non-staining yolk; developed chorion \\
5 & Running ripe & Homogeneous red-staining yolk; oocytes hydrated; \\
& & development complete \\
6 & Spent & Atresion of ripe oocytes plus pre-vitellogenic \\
& & oocytes; presence of post-vitellogenic follicles
\end{tabular}

ovaries containing developing oocytes at each stage and Wright (1992) that several oocyte groups in different stages of maturation can be recognised in the mature ovary of $E$. heterolobus. Wright (1992) stated that this anchovy is a serial spawner (ranging from 2 to 14 days). According to Tiews et al. (1970) E. heterolobus in the Philippines probably spawns at least twice during its life.

In this study we found ovaries with postvitellogenic follicles in $18 \%$ of fish in september 1996 (out of 34 samples collected from three occasions), $3 \%$ of fish in November 1996 (out of 148 samples collected from two occasions), $68 \%$ of fish in April 1997 (out of 448 samples collected from 4 occasions), $67 \%$ of fish in June $(n=54$ from 1 occasion), and $45 \%$ of fish in July 1997 (out of 481 samples collected on 4 occasions). The six gonad maturity stages are shown in Figure 1.

Each fish one stage is always more dominant than any other at a particular time, depending on when it last spawned and when it will next spawn. The sequence is shown for each day of sampling for each sampling trip in Figure 2, and also for all samples combined for each trip in Figure 3. These figures graphically demonstrate the variability between sampling periods and the day to day variation in the contributions of populations of female $E$. heterolobus to overall egg production. It further emphasises the importance to the Daily Egg Production Method of sampling the anchovy population for female spawning information at the same time as the plankton is sampled for eggs.

\section{Acknowledgments}

We thank Ms. Tonya Van der Velde of CSIRO Marine Research for assistance with histology and
Ms. Pradina Hatta of the Indonesian National Science Institute for photography. This work formed part of the baitfish research project funded by Australian Centre for International Agricultural Research.

\section{REFERENCES}

Cyrus, D.P. and Blaber, S.J.M. 1984. The reproductive biology of Gerres (Teleostei) Bleeker 1859, in Natal estuaries. J. Fish. Biol. 24: 491-504.

Hunter, J.R. and Goldberg, S.R. 1980. Spawning incidence and batch fecundity in northern anchovy Engraulis mordax. Fish. Bull. U.S. 77: 641-652.

Luna, L.G. 1968. Manual of Histological Staining Methods of the Armed Forces. Institute of Pathology. 3rd ed. McGraw-Hill, N.Y.

Milton, D.A. and Blaber, S.J.M. 1991. Maturation, spawning seasonality, and proximate spawning stimuli of six species of tuna baitfish in the Solomon Islands. Fish. Bull. U.S. 89: $221-237$.

Milton, D.A. Blaber, S.J.M and Rawlinson, N.J.F. 1994. Reproductive biology and egg production of three species of Clupeidae from Kiribati, tropical central Pacific. Fish. Bull. U.S. 92: $102-121$.

Sumadhiharga, O.K. 1995. Anchovy Fisheries and Ecology with Sperial Reference to the Reproductive Biology of Stolephorus spp. in Ambon Bay, Indonesia. $\mathrm{PhD}$ Thesis. University of Tokyo, Japan. $143 \mathrm{pp}$.

Tiews, K., Ronquillo, L.A.and Santos, L.M. 1970. On the biology of anchovies (Stolephorus, Lacépède) in Philippine waters. Proceedings of the Indo-Pacific Fisheries Council 13(II): 20-48.

Wright, P.J. 1992. Ovarian development, spawning frequency and batch fecundity in Encrasicholina heteroloba (Rüppell, 1858). J. Fish. Biol. 40: 833844 . 




Figure 1. Histological sections of the gonads of Encrasicholina heterolobus showing the six stages of maturity. 


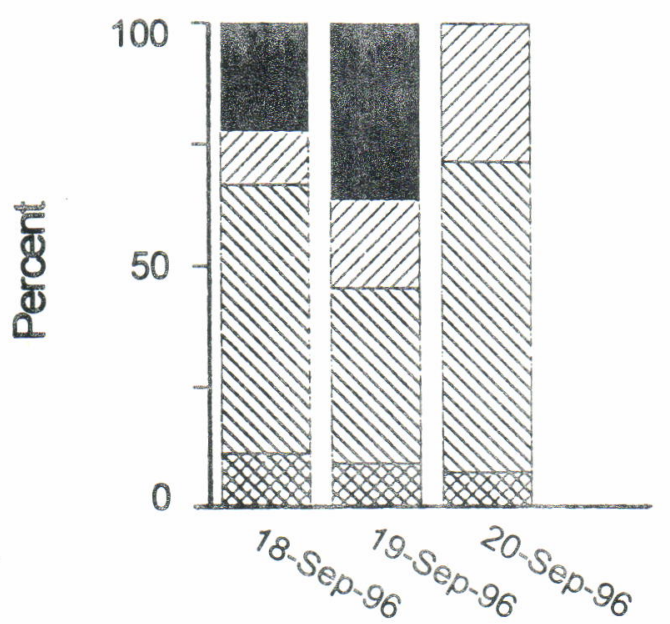

$N=9 \quad N=11 \quad N=14$

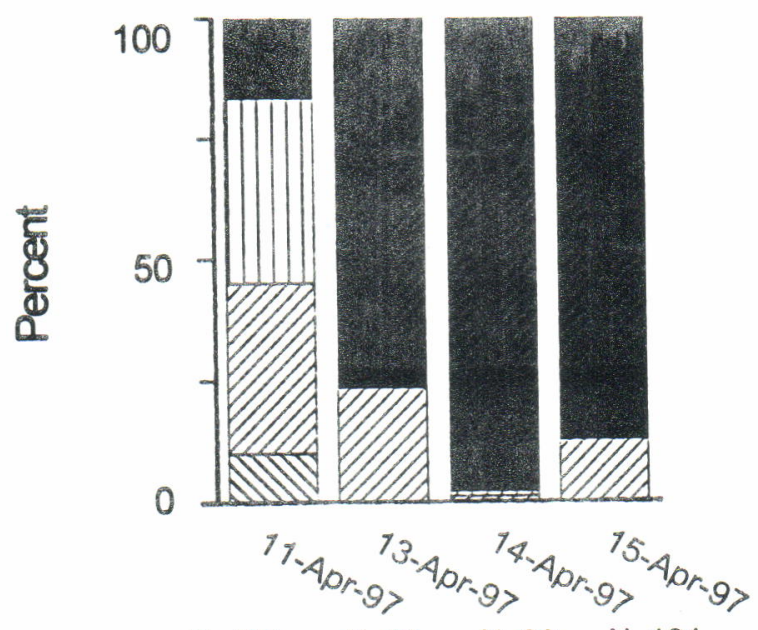

$N=120 \quad N=98 \quad N=96 \quad N=134$

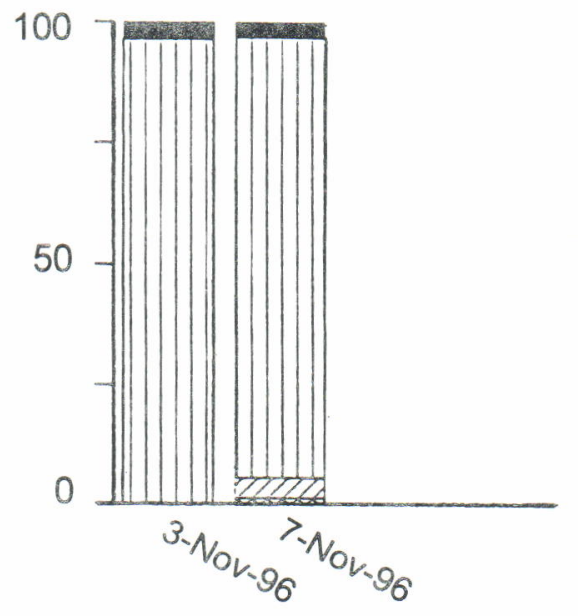

$\mathrm{N}=55 \quad \mathrm{~N}=93$

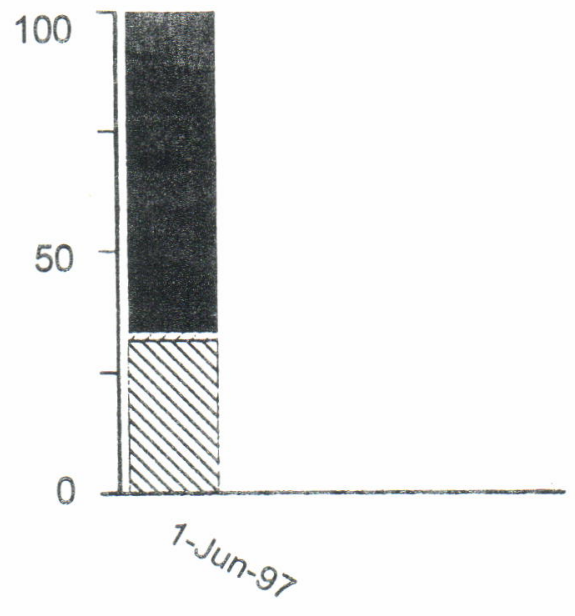

$\mathrm{N}=54$

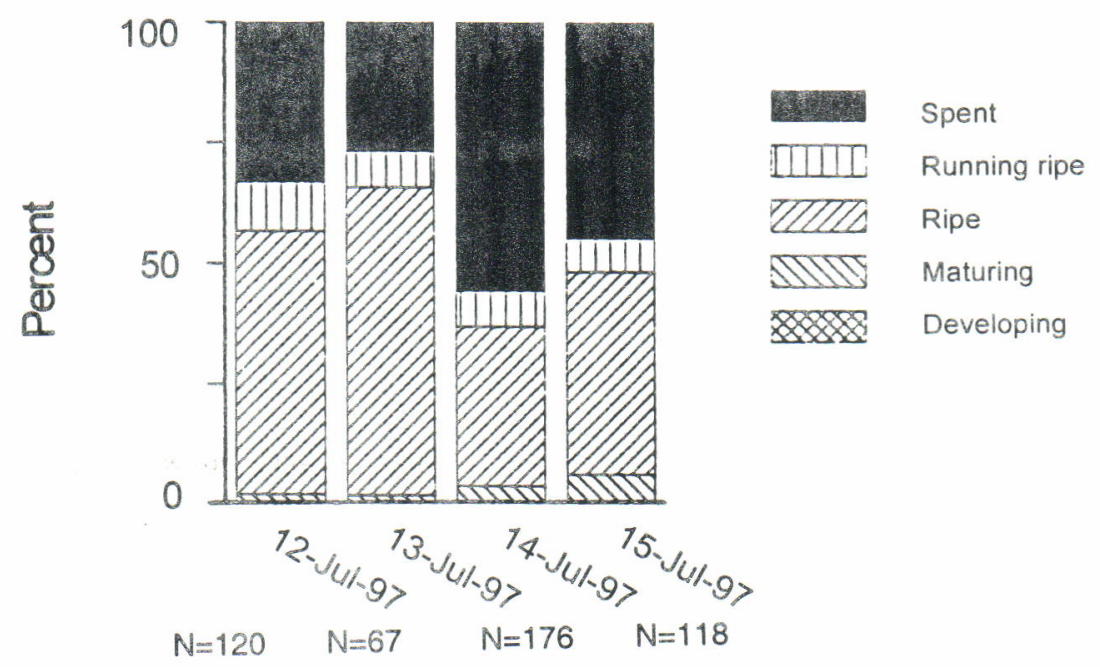

Figure 2. Proportions of each maturity stage in the gonads of Encrasicholina heterolobus from each day's sample from five sampling trips. 


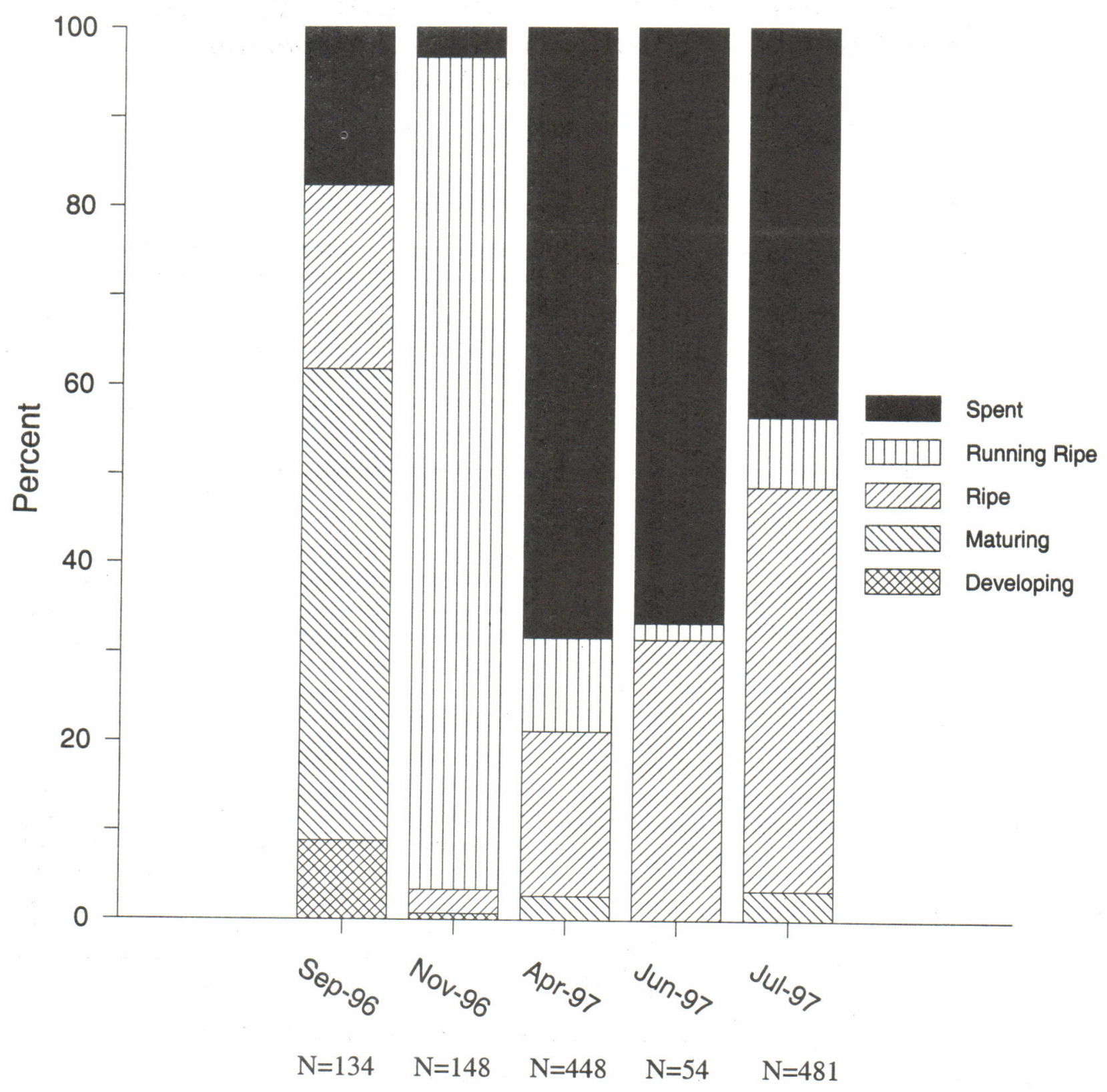

Figure 3. Proportion of each maturity stage in the gonad of Encrasicholina heterolobus for all samples combined for each of the five sampling trips. 